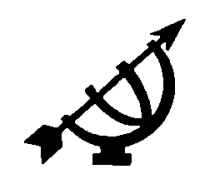

\title{
School-based management: implications for the new roles of principals and teachers
}

\author{
M.J. Mosoge \& P.C. van der Westhuizen \\ Graduate School of Education \\ Potchefstroom University for CHE \\ POTCHEFSTROOM \\ E-mail: dopmjm@puknet puk ac.za \\ doppcvdw@puknet.puk.ac.za
}

\begin{abstract}
School-based management: implications for the new roles of principals and teachers
\end{abstract}

\begin{abstract}
Recent reform policy in education rests on the implementation of school-based management. This policy implies new roles and responsibilities for the principal and teachers in the management of schools. Consequently, this paper explores school-based management with regard to the devolution of authority, leadership styles, decentralization of school functions and teacher participation.
\end{abstract}

\section{Orientation}

Educational reform and restructuring initiatives in most parts of the world rest on the conviction that the participation of teachers, leamers and parents can enhance the achievement of the desired transformation. On its own, participation is deemed to have substantial benefits for the school and its members. In this respect, participation is deemed to increase morale and productivity (Johnstone \& Germinario, 1985:91; Chapman, 1988:57), elicit acceptance of and commitment to decisions (Weiss, 1992:3) and contribute to improved student achievement (Perry et al., 1994:605).

Such reform initiatives may be defined by different terms, however, with schoolbased management, shared decision-making, participatory decision-making, decentralization, empowerment, school-based decision-making and site-based management being the most popular terms (Walker \& Roder, 1993:164). In the RSA the preferred term, as used in most educational policy documents, and which will be used in this article, is school-based management. Whichever term 
is used, school-based management generally refers to a decentralized form of management in the education system. The school becomes the locus for decision making and the participation of parents, learners and teachers is evident.

School-based management is no longer an option of which the merits can be debated. In most countries school-based management is mandated through legislation. In the RSA in particular, it has been enacted through the South African Schools Act (Republic of South Africa, 1996). As acknowledged by many commentators (Wildy, 1997:2; Leithwood et al., 1997:2; Marsh \& LeFever, 1997:1), school-based management casts principals, teachers, learners and parents into new roles and responsibilities.

Perceptions of the roles of principals and teachers in the implementation of school-based management are often at variance with the Scriptural ontic principles of the school as a societal relationship. The authority structure of the school in particular is often ignored. Consequently, "the calling and office" (Fowler, 1996:106) of various school members comes under strain in the performance of management duties. Moreover, the distinctive end towards which the school must work and thereby serve its Creator, viz., teaching-learning, is often sacrificed on the altar of democracy.

This article explores the new roles of principals and teachers in school-based management from the viewpoint of the Scriptural ontic principles of the school and of management with respect to authority, leadership and the extent of participation. To place the roles of principals and teachers in perspective, the article will first consider how school-based management is conceptualized.

\section{Conceptualization of school-based management}

The view taken in this article is that the participation of teachers within the bounds of school-based management occurs in an area with which they are unfamiliar, while it requires of principals to share authority and leadership with teachers and other stakeholders. Thus, to understand how this arrangement impacts on the role of principal and teachers, it is necessary to review what school-based management entails.

In the traditional bureaucratic system authority and decision-making are vested in the hands of officials at a "central office" who ratify the decisions from school level (McWalters, 1992:9). School-based management represents a departure from this type of system. It attempts to move the decision-making process from the central office to the school. The devolution of authority through decentralization is, therefore, the first dimension of school-based management. Hence the concept of a "self-managing school" is encapsulated in school-based management (Department of Education, 1996a:29). 
The second dimension of school-based management relates to the participation of stakeholders. In the process of delegating authority, all stakeholders concemed with the management of a school (parents and teachers) take responsibility for the internal management of a school (Department of Education, 1996a:28). Often the internal functioning of a school is divided into managing and teaching spheres with each sphere managed by different categories of persons. Hence the popular saying that the role of the principal is to manage while that of the teachers is to teach.

Lately the terms "management" and "governance" have been used to differentiate the roles of principals and other stakeholders (i.c. teachers) in school management. White Paper II (Department of Education, 1996b:15) defines governance as the sphere of policy determination - a sphere in which democratic participation is essential; management is defined as the day-to-day organization of teaching and learning - a sphere for which principals and teachers are responsible. As admitted in White Paper II (Department of Education, 1996b) the duties of govemance and management overlap and, it may be added, can hardly be differentiated.

In Article 16 (1 and 3) the South African Schools Act (Republic of South Africa, 1996) determines that the professional management of a school must be undertaken by the principal and the head of an Education Department, while governance is vested in the Governing Body (consisting of parents, teachers and learners).

The above-mentioned guidelines create the impression that the aspect of professional management of the school falls outside the scope of teachers. Oosthuizen (1994:128) expresses the opinion that certain duties exercised by the principal require a high degree of managerial responsibility and authority and can, therefore, not be delegated. The sphere of teachers' management duties is restricted to pupils' activities with regard to the social, academic and physical aspects of school life (Prinsloo \& Van Rooyen, 1997:356).

While it is accepted that parents' and learners' participation may be limited to governance only, the same cannot be said about teachers. Teachers should be involved in the governance and professional management of a school, as suggested in White Paper II (Department of Education, 1996a:26) because they, like principals, daily grapple with problems requiring immediate managerial response. The third dimension of school-based management, therefore, concerns the participation of teachers in school management, together with the principal and the senior management team.

The practice of teachers participating in school management is not totally new The recognition of this practice pays tribute to all hardworking teachers who, 
over the years, have sacrificed their time to assist principals with managerial duties. Thus, Walker and Roder (1993:160) are right in defining school-based management as "a management system where persons not historically involved in the decision-making process are allowed to participate in the management of their school".

Having briefly mapped what school-based management entails, the next question to answer is: What are the respective roles of principals and teachers with regard to authority, leadership and the extent of participation in school management? The ensuing paragraphs attempt to provide an answer to this question.

\section{Authority in school-based management}

Authority serves as the basis for getting things done in a school as it equips its bearer with legitimate power and influence. Both principals and teachers, as office bearers under God, are endowed with authority; each exercises this Godgiven authority, however, in accordance with his/her calling within the communal institution. Consequently, the authority of principals and that of teachers will be discussed separately for the sake of indicating their respective roles.

\subsection{Authority of principals}

Van der Westhuizen and Mentz (1996:27) argue that a school, both as a societal relationship and as an organisation, exhibits a hierarchical authority structure. At the head of this structure is the principal. Principals derive their authority from man's creational mandate of regulating societal structures and thus exercising granted authority from God who is sovereign master of the entire creation (Van der Westhuizen, 1997a:12)

Principals positivize their authority by means of rules and regulations which are applicable to the whole school, so as to regulate the mode of living together within the sphere of the school (Van der Westhuizen \& Mentz, 1996:25). Since it is God who vests man (i.c. principals) with authority, man must execute his authority in a responsible way, thus guiding and taking care of those who are subordinate to his authority. The exercising of authority implies influencing the behaviour of individuals in the direction of achieving organizational goals.

The above-mentioned guidelines, however, do not imply that principals must use their authority to oppress opinions of other school members. The creational mandate requires that principals should exercise authority in a responsible way in order to promote the societal structure. In school-based management principals are not expected to give detailed instructions which teachers must follow without question. Principals should exercise their authority with due regard for the 
opinions of teachers and should encourage teachers to take the initiative, make decisions and exercise their dominion over creation (Fowler, 1996:101).

It seems as if recent demands for participation in school management have often been based on a misinterpretation of authority as meaning authoritarianism. It has not been uncommon for people to speak of reducing the enormous power and influence concentrated in the position of principalship, or to suggest the flattening of the school's hierarchical structure, or to render principals superfluous (Walker \& Roder, 1993:166). Despite efforts to achieve the foregoing, the hierarchical structure remains the most powerful tool for employing large numbers of people, yet retaining unambiguous accountability (Jaques, 1991:57). The authority of the principal is, therefore, immutable because it is the ontic given of the school as a communal institution.

\subsection{Authority of teachers}

God, as bearer of final and absolute authority, has endowed teachers with authority, and similarly principals. The teachers' authority, however, is not the same as that of principals. According to Van der Westhuizen and Mentz (1996: 27), authority in the sphere of the school is clearly demarcated. Thus, principals have overall management authority while teachers exercise authority in the classroom. Teachers' authority enables them to create an orderly environment in their classrooms so as to allow effective teaching and learning to take place.

The authority of teachers is limited and circumscribed by their God-given calling as teachers in the school. This idea is in harmony with the Scriptural teaching of man as office-bearer under the authority God. The authority of teachers is bound to their educative office for leading children in their exploration of creation (Fowler, 1996:104). Teachers regulate classroom affairs by applying rules to govern the behaviour of children under their care. Teachers should respect the children they teach and value their opinions, even though such opinions may vary from theirs. It may be said then that teachers' authority does not imply to shape the whole character of the school.

Complexities of school management and the utilization of participative management, however, necessitate the delegation of authority from higher to lower levels, for example, to Heads of Department and teachers. Thus, teachers are at times placed in positions of authority with regard to limited areas of school functioning, e.g. sports. In such cases, teachers act in a position of authority visà-vis their colleagues and should be accorded the same respect as though they occupy formal positions.

Some teachers, under the new dispensation, are elected to serve in policy-making bodies such as the Governing Body. Within the limits of their elected positions 
teachers may exert influence on school-related policies. This is the essence of their participation in school management.

The sharing of authority in school-based management does not imply that principals abdicate their authority - thereby forsaking their God-given mandate but that they delegate authority to others in the school to enable them to perform delegated duties. Since the authority of teachers also emanates from God, the role of teachers is to support, not to replace the principal and to uphold, not undermine, the principal's authority so that effective educative teaching can take place. In this way, teachers will be using their positions in decision-making bodies in the school to serve their God-given office of educative teaching thereby also serving God.

\section{Leadership in school-based management}

The position of principalship renders both authority and leadership to the incumbent. To manage a school effectively, principals need to be both managers and leaders. Merely executing the tasks of planning and organizing does not transform a manager into a leader. Van der Westhuizen (1997c:187) defines leadership as the ability of a person "to convince, inspire, bind and direct followers to realise common ideals".

The culture of a democratic order displayed in school-based management requires principals to exercise a leadership style which promotes participation of stakeholders. Van der Westhuizen (1997a:28) states that, since the Fall, man's authority tends towards the extremes of authoritarian and laissez faire types of leadership. Neither type of leadership is envisaged in school-based management.

The collaborative setting of school-based management calls upon principals and teachers to exercise leadership in various roles in a school, namely, in the field of visionary and moral leadership, transformational leadership and in respect of being developer and mentor. The above roles will be explained in the ensuing discussion.

\subsection{Visionary leadership}

A school's independence of external controls requires it to set its own mission, goals, policies, strategic plans, and evaluation strategies. As visionary leaders, principals provide inspiration and purpose to the school's endeavours by focusing the attention of teachers, learners and parents on the mission and goals of the school (Laws et al., 1992:52)

Principals should rally people around a set of ideals which represent the shared expectations, beliefs and values of the school and utilize these ideals or mission to guide and give direction to educational activities. Christian principals will also 
have an overriding vision to find renewed conformity to the structural ordinance of the school in Christ (Wolters, 1993:73).

By developing a strong school ethos based on Scriptural principles, principals will be able to encourage and support members to work hard, to be committed and to be fully involved in achieving the central purpose of the school, viz., educative teaching. The vision of Christian principals should be to lead their subordinates to honour and glorify God (Theron \& Van der Westhuizen, 1992:134).

While visioning and the formulation of the school's mission fall within the purview of principals and the senior management teams (Kroon, 1990:172), school-based management affords teachers an opportunity to participate in this exercise. Their role consists of developing and interpreting the original vision of the senior management. Where such a vision is not consistent with the Scriptural mission of the school, Christian teachers should not hesitate to exercise their reformational task of re-directing it towards God.

Once agreement concerning the school's mission has been reached in the Governing Body, teachers should implement it in their classrooms as it befits their specific office of educative teaching. Instead of merely articulating the school's vision to the learners, teachers should act as positive role models because children learn more easily by example than by words. Teachers should also use every available opportunity during parents' evenings to inform parents about the school's vision.

\subsection{Moral leadership}

Moral leadership provides an anchor for transformational leadership. Attempts of principals may easily lose direction if not grounded on principle. Matczynski and Benz (1997:2) offer the following explanation of moral leadership: "Moral leadership connotes the use of values and value judgements in the selection, extension and day-to-day practices of educational leaders. A moral leader is consistently cognizant of the central purpose of schooling."

In managing a school, principals should always strive to satisfy the expectations of the community with regard to the way in which a school ought to be managed (Van der Westhuizen, 1997b:88). However, principals should also identify values which have a basis in Scripture and shape their management of the school in accordance with these values.

Principals would do well to advise the Governing Body to consider the appointment of teachers, not only on the basis of teaching expertise, but also on the basis of their values. It is the principals' duty to guide teachers in upholding the professional code of conduct and to deal with deviations promptly, yet fairly. 
It is obligatory for Christian teachers to exercise their moral leadership in the community by correcting faulty values through increasingly affirming God's law on the school as a societal relationship (Van der Westhuizen, 1997b:131). This goal can be achieved when teachers act as leaders in the community, for example, in the capacity of catechists, elders, deacons or Sunday school teachers, or as chairpersons or secretaries in a variety of community-based organizations (Loots, 1992:33)

The conduct of teachers should always be above reproach, especially in carrying out duties allocated to them in the Governing Body and in the management of a school. Teachers should feel morally obliged to perform management duties faithfully and not to regard such duties as an unnecessary burden.

\subsection{Transformational leadership}

The onticity of transformational leadership is embedded in God's command for man to fill the earth and subdue it and to cultivate the earth from which he was taken. Man was thus given authority to work with creation, fashion it, shape it and transform it (Fowler, 1996:88-89). Restructuring and change are therefore part of the mandate of principals and teachers to transform the reality of which the school forms part. Fowler (1996:89) is of the opinion that if man left creation as it was given to him, this action would amount to disobedience to God.

In this context principals and teachers are called upon to balance transactional leadership with transformational leadership. Transactional leadership involves the discharge of basic managerial functions which are necessary for the functioning of the organization. Van der Walt (1996:22) aptly summarizes transactional contracts as "a fair day's work for a fair day's pay". For the Christian leader transactional leadership is not enough. In carrying out his/her cultural mandate, the Christian leader is constantly looking for ways of cultivating and improving creation.

Although no agreement exists on what transformational leadership entails (Leithwood et al., 1997:4), it could be said that it entails anticipating and responding to the demands of the environment. According to Bennis (1984:67), transformative power is "the capacity to take an organisation to a place where it has never been before". This means that principals should change the mind-set of people, their attitudes, values, and ways of doing things. To achieve this, principals must steadfastly pursue the purposes for which the school has been established. They should give advice to school members, solicit advice from experts outside the school, utilize networking with other institutions, and form partnerships with industry and other educationally interested structures (Department of Education, 1996a:70) 
Teacher leaders provide a key towards the transformation of the school system. They should act as facilitators of change, bring about innovative teaching and generally support measures aimed at improving the teaching-learning situation. Indeed, Christian teachers' greatest role at policy-making level lies in the continual development of the school curriculum in the light of Scripture. Teachers should also encourage their colleagues to improve themselves by inservice training courses enabling them to participate in an informed way in the drawing up of new curricula.

\subsection{Leadership by being a developer and mentor}

As indicated previously, the hallmark of school-based management is the empowerment of school members to make decisions about how a school should operate. The Department of Education (1996a:31) asserts that schools should not only serve as learning environments for learners, but also for teachers and parents - a place for teachers, principals, parents and leamers to live and grow.

The principal should actively seek to develop his staff by creating opportunities for them to grow, to learn from each other and to learn from their mistakes. Short (1994:490) is of the opinion that as people grow, they learn to judge their own abilities better, discover their own interests and develop their basic potential. The leadership of principals in school-based management implies that they further act as mentors to enable teachers to develop their leadership potential.

Teachers' leadership is not confined to school-based management; it can also be practised in traditional management. Besides the formal positions, such as Head of Department, teachers also act as informal leaders in a school - for example, as project leaders, sharing their expertise with colleagues, serving in ad-hoc committees and in the myriads of committees created in schools to serve specific purposes unique to a particular school.

As in other countries (Leithwood et al., 1997:3), teachers in the RSA also serve as members of the Governing Body (Republic of South Africa, 1996:16) Principals should recognize the fact that teachers also exercise leadership in the context of the school as a whole and not only in relation to their teaching duties. Such teacher leaders need the support and encouragement of the principal to enable them to perform their duties effectively (Short, 1994:495).

In school-based management teachers serve as developers and mentors of their colleagues. The delegation of authority encourages teachers to plan together, share ideas and seek help from others. It also implies that teacher leadership should be accepted by others as a matter of course and not be resisted on the grounds that the teacher leader does not occupy a formal position of authority. School-based management effectively legalizes the erstwhile informal leadership 
exercised by teachers. Leithwood et al. (1997:3) mention that teacher leaders perform a variety of functions, such as stimulating the professional growth of others, inducting new teachers, and positively influencing their colleagues to implement change.

\section{The extent and level of participation in school-based management}

The roles of principals and teachers in a participatory setting should be evaluated on the basis of the ontic laws with regard to their respective offices. Neither office should suffer in school-based management. Legislative mandates and the establishment of democratic school governance structures do not guarantee that principals and teachers will participate effectively. Thus it is important to demarcate the extent and level of their participation in school management.

\subsection{Extent of participation}

The extent of participation refers to the choice of individuals who should be involved and the range of their participation in an issue, action or task at hand. Obviously not all individuals in a school are interested in participating in all activities of management, nor are they all equipped with the necessary knowledge and expertise to participate effectively.

In the era of democratization an erroneous idea may arise that principals should just be ex officio members with marginal participation in school governance. The South African Schools Act (Republic of South Africa, 1996:18) grants principals full participative powers in both school governance and especially in the professional management of a school. This governing principle is in line with the authority and leadership position of principals, vis-à-vis the school as a societal relationship and an organization.

Principals should, therefore, take responsibility and accountability for the participation of other stakeholders in school management. They should give guidance particularly to teachers, to elect members who have the motivation, interest, expertise and knowledge so that their participation can be effective. Principals should ensure the success of participation by disseminating information, facilitating negotiation, liaising with outside bodies, monitoring the implementation of resolutions and mediating conflicts (Van der Westhuizen, 1997b:94-95).

The possibility exists that entire staffs of schools do not have a grounding in participation because of the fairly recent idea of school-based management. Since teachers are, in this respect, involved in an unfamiliar area, it is likely that they are not acquainted with what school management entails. Schools should 
adopt a multiple-strategy approach in training and equipping teachers for their new roles. Principals should assist, support and create opportunities for teachers to receive relevant training and must themselves also undergo training.

Events in some schools of the ex Department of Education and Training showed that teachers erroneously expected to be involved in all aspects of management and in all issues surfacing from time to time. This idea may prove to be impossible, illogical and dysfunctional (Hoy \& Tarter, 1993:14) and at variance with the ontic mandate of their office of educative teaching.

Consequently, participation of teachers in school management should be carefully implemented lest the teachers' ontic office suffers in the process. It will not serve a positive purpose should teachers be so involved in school management that they neglect their teaching responsibility. They should be prepared to sacrifice their time and attend meetings after school and during weekends. The right of teachers to participate and even demand participation makes it unacceptable that they should opt out of committees as they wish or attend meetings whenever they feel like it.

The constituency represented by teachers should understand that decisions reached with the participation of their members are binding. Moreover, the representatives are not merely the carriers of the teachers' desires, but are also authorized, as leaders, to take decisions on behalf of their constituency in the interests of educative teaching. The elected teachers should understand their role as representatives of their constituency. They should regularly give feedback to their constituency with an explanation why certain decisions were taken in order to obtain fresh mandates from the constituency.

Attendance of a meeting does not connote participation. Participation may range from very little participation to extensive participation (Hoy \& Tarter, 1993:7). Teachers should strive for maximum participation in order to ensure an informed generation who is ready to improve the quality of decisions. Participation, however, does not imply that people should discuss something endlessly, having the wrong impression that everyone must have a say. The discussion should focus on the objectives of the meeting or the issues at stake

\subsection{Level of participation}

School-based management involves the issue of the devolution of authority and responsibility from the central office to the school site. The level of participation refers to the amount of decision-making accorded to the school. This means drawing a line between decisions accorded to the school and those executed by the central Education Department, and expressing without ambiguity, their respective competencies and functions (Prinsloo, s.a.:67). This action becomes 
more significant in the light of the commitment by the Ministry of Education in the "new" South Africa to limit State involvement required for legal accountability to the minimum (Department of Education, 1996b: 70).

Drawing the line between the central education office and the school is a difficult and sensitive issue (Torres, 1992:14) because this line is "wiggly and gray" as Lebowitz (1992:12) puts it. The Department of Education has opted for an incremental model by which each school is given a basic set of responsibilities. The school can then negotiate for additional powers as it gains experience, capacity and confidence (Department of Education, 1996a:17).

Principals should note that the success of self-management of schools depends on honest retrospection by school members concerning what they are capable of doing. Due to resistance to change, it is probable that some of the teachers will not be ready to accept participation, preferring to be directed and controlled; others might prefer to remain on the sideline while issuing scathing criticism against principals and those who accept change.

Principals should apply all possible measures to remove this resistance to change. They should assume the role of change agents. With their wealth of experience, principals are in a good position to know educational legislation and rules. This knowledge should be used to guide teachers on the parameters of their participation.

The school, being part of a larger system, should undertake its own needs assessment, develop its own mission and set its own goals within the parameters set by the Education Department. Teachers need to set own goals concerning their classrooms and the school-specific areas in which they have been allocated leadership positions. A vital role can also be played by teachers in identifying their own training needs with the assistance of the principal and professional facilitators.

\section{Conclusion}

School-based management is embedded within the context of an authority structure for the school. The main authority-bearer in charge of the school in its totality is the principal, while teachers are authority-bearers with respect to their classrooms. Teachers also exercise delegated authority in selected areas of management covering all aspects of school management. This implies that teachers, like principals, should exercise their authority and leadership in a responsible way to provide educative teaching to learners. In this way, schoolbased management takes into account the authority structure, thereby complying with the ontic given of the school as a societal relationship and as an organization. 
The success of leadership in school-based management hinges on the sharing of and respect for prevailing values in the community. Christian principals and teachers should be sensitive to these community values and always model values which uphold God's laws. Such leadership is in line with Scriptural leadership.

The participation of principals and teachers in school management should be based on their respective offices and calling within the societal structure. Schoolbased management affirms the right of principals to be principals and teachers to be teachers. Thus, each party is afforded sufficient room to contribute towards the development of a school. As such, the principle of the central function of the school as a God-given structure is respected.

School-based management is not a passing fancy nor a cosmetic change but an enduring phenomenon which should continuously be realigned with God's ordinances so that each school may responsibly renew its management and its members. To produce the undoubted benefits offered by school-based management will, however, take time, patience, grit and persistence.

\section{Bibliography}

BENNIS, W. 1984. Transformative power and leadership. (In Sergiovanni, T.J. \& Corbally, J.E. eds Leadership and organizational culture: new perspectives on administrative theory and practice. Chicago : Illinois Press p 64-71.)

CHAPMAN. J.D. 1988. Decentralization, devolution and the teacher: participation by teachers in the decision making of schools. The Journal of Educational Administration, 26(1):37-39

DEPARTMENT OF EDUCATION. 1996a Changing management to manage change in education: report of the task team on education management development. South Africa : Department of Education.

DEPARTMENT OF EDUCATION. 1996b. Education White paper 2: The organisation, governance and funding of schools. Pretoria : Government Printer.

FOWLER, S. 1996. Christian educational distinctives. Potchefstroom : Centre for Faith and Scholarship.

HOY, W.K. \& TARTER, C.J. 1993. A normative theory of participative decision making in schools Journal of Educational Administration, 31(3):4-19.

JAQUES, E 1991. A dissenting view: in praise of hierarchy. (In Harvard Business Review, Participative management. Boston : Harvard College. p. 57-63.)

JOHNSTONE, G.S. \& GERMINARIO, V. 1985. Relationship between teacher decisional status and loyalty. Journal of Educational Administration, 23(1):91-105.

KROON, J. 1990. Bestuur en bestuurder. (In Kroon, J. red. Algemene bestuur. Pretoria Haum. p. 3-24.)

LAWS, K., SMITH, D. \& SINCLAIR, K 1992. Leadership style, skills and technology. (In Turner, C., Hatton, M., Laws, K., Sinclair, K and Smith, D. The school manager Sydney : Allen \& Unwin. p. 44-89.)

LEBOWITZ, A.J. 1992. Staff buys in through shared decision making. The School Administrator, $49(1): 12-13$ 
LEITHWOOD, K., JANTZI, D , RYAN, S \& STEINBACH, R. 1997. Distributed leadership in secondary schools (Paper presented at the Annual Meeting of the American Educational Research Association, Chicago, March 1997)

LOOTS, Z.B. 1992. Die onderwys as professie. (In Van der Westhuizen, P C, Loots, Z B Mentz, P.J., Oosthuizen, I.J. \& Theron, A.M.C Die beginneronderwyser: 'n bestuurmatig-juridiese perspektief Durban : Butterworths. p. 11-34.)

MARSH, D D \& LeFEVER, K. 1997. Educational leadership in policy context: what happens when student performance standards are clear? (Paper presented at the Annual Meeting of the American Educational Research Association, Chicago, March 1997.)

MATCZYNSKI, T J \& BENZ, C.R 1997. Alternative principal preparation program: an experimental approach (Paper presented at the Annual Meeting of the American Educational Research Association, Chicago, March 1997 )

McWALTERS, P 1992. Handing accountability and authority to schools The School Administrator, 49(1) 9-10.

OOSTHUIZEN, I.J. 1994. Personnel management (In Oosthuizen, I J. ed Aspects of educational law for educational management. Pretoria. Van Schaik p 119-134)

PERRY, C M., BROWN, D W \& McINTIRE, W.G. 1994 Teacher respond to the shared decision making opportunity. Education, 4(114):605-608.

PRINSLOO, NP s.a. Besluitneming in onderwysbestuur. Pretoria : Universiteit van Pretoria.

PRINSLOO, N.P. \& VAN ROOYEN, J W. 1997. The management of pupil activities (In Van der Westhuizen, P C. ed. Effective educational management Pretoria : Kagiso p. 347-368.

REPUBLIC OF SOUTH AFRICA. 1996 South African Schools Act. Vol 377. Pretoria Government Printer.

SHORT, P.M. 1994. Defining teacher empowerment. Education, 4(114):493-502.

THERON A M C. \& VAN DER WESTHULZEN, P C. 1992. Die onderwyser en sy bestuurswerk. (In Van der Westhuizen, P C., Loots, Z B, Mentz, P J., Oosthuizen, I J. \& Theron, A.M.C. Die beginneronderwyser: 'n bestuurmatig-juridiese perspektief. Durban : Butterworths. p 11-34.)

TORRES, H. 1992 Wrestling with what to include in SBM. The School Administrator, 49(1): 14

VAN DER WALT, J.L. 1996. The psychological contract as enabling instrument in the management of a Faculty of Education Potchefstroom : PU vir CHO.

VAN DER WESTHUIZEN, P C. \& MENTZ, P J. 1996 An ontological perspective on the school as an organisation. (In Van der Westhuizen, P C ed Schools as organisations Pretoria : Van Schaik. p. 22-74)

VAN DER WESTHUIZEN, PC. 1997a. Perspectives on educational management and explanation of terms. (In Van der Westhuizen, PC ed Effective educational management. Pretoria : Kagiso. p 11-61.)

VAN DER WESTHUIZEN, P C. 1997b. The development of scientific management thought and some developments in the field of educational management (In Van der Westhuizen, P C. ed. Effective educational management Pretoria : Kagiso. p 63-161.)

VAN DER WESTHULZEN. P.C 1997c. Educational management tasks (In Van der Westhuizen, P C. ed Effective educational management Pretoria : Kagiso p 135 235.)

WALKER, P.A. \& RODER, L. 1993 Reflections on the practical and legal implications of school-based management and teacher empowerment Journal of Law and Education, 22(2) : 159-175. 
WEISS, C.H. 1992. Shared decision making about what? (Paper presented at the Annual Meeting of the American Educational Research Association, San Francisco, April 21, 1992.)

WILDY, H. 1997. Restructuring and principal's power: neither freedom from nor freedom to. (Paper presented at the Annual Meeting of the American Educational Association, Chicago, March 1997.)

WOLTERS, A.M. 1993. Creation regained: biblical basics for a Reformational worldview. Grand Rapids : Eerdmans. 